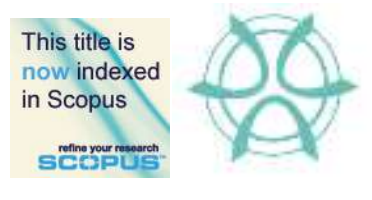

PLANNING MALAYSIA:

Journal of the Malaysian Institute of Planners

VOLUME 18 ISSUE 4 (2020), Page 80 - 91

\title{
MODERATING EFFECT OF SERVICE QUALITY ON PUBLIC TRANSPORT TRAVEL BEHAVIOUR AND ANTECEDENTS
}

\author{
Rohana Ngah ${ }^{1}$, Lennora Putit ${ }^{2}$, Azmi Mat ${ }^{3}$, Jamalunlaili Abdullah ${ }^{4}$, \\ Rohayu Ab Majid ${ }^{5}$ \\ 1,2,3,4,5 Faculty of Business and Management, \\ UNIVERSITI TEKNOLOGI MARA (UiTM)
}

\begin{abstract}
Public transport infrastructure has been massively developed to encourage public transport usage in Kuala Lumpur. However, a low percentage of public transport ridership dampens the objectives to reduce traffic congestion and air population. This paper attempts to investigate the effect of travel intention and the moderating effect of general service quality of public transport on travel behaviour among commuters in Kuala Lumpur. A survey was carried out at LRT stations, and a total of 904 were usable. Most of the respondents are young adults between 2029 years old, and the majority earned less than RM3,000 a month. Most of them possess a vehicle and driving license. Findings showed that travel intention has a significant effect on travel behaviour. Interestingly, service quality, in general, weakly moderates the relationship between travel intention and travel behaviour in a reverse direction. The findings would help relevant authorities to set strategies to encourage more private riders further to switch to public transport.
\end{abstract}

Keywords: Public transport, travel intention, travel behaviour, service quality

${ }^{1}$ Assoc. Professor at FBM, UiTM. E-mail: rohanangah@uitm.edu.my 
PLANNING MALAYSIA

Journal of the Malaysia Institute of Planners (2020)

\section{INTRODUCTION}

Transportation is a vital driver of cities' development by providing safe, efficient, and reliable transportation for people, goods, and services (Tai et al. 2016; Choi $\&$ Loh, 2013). When the population of urban cities increases rapidly, traffic problems in metropolitan areas such as lack of space and congestion, and poor air quality, also increase (Zhang and Baterman, 2014). Public transportation becomes a necessity to reduce traffic congestion, increase productivity, and reduce carbon emissions. Public transport is essential for people's movement and mobility (Mat et al., 2019). This situation expanded the need for motorized travel, thus increasing the travel demand. Despite a massive public transport infrastructure development have been carried out in Kuala Lumpur, however, the public transport ridership is only $20 \%$ (APAD, 2017; Gerber, 2018) compared to Singapore (50\%) and Hong Kong (83\%) (LTA, 2018). Few studies have been carried out on travel behaviour in Malaysia but still inconclusive. The application of the theory of planned behaviour posits that travel intention is an important precondition of travel behaviour (Ribeiro et al. 2017). Also, attitude and norming are a common predictor of intention. Many factors influence behavioural intentions and increase the probability that commuters will behave.

Meanwhile, urban transport development remains an important issue for public authorities as so assuring the service quality. For example, in the Malaysian context, public transport service is part of the underlying infrastructure and essential in the development of a country. Service quality is also one of the most important determinants of public travel demand (Polat, 2012). The increased relevance of end-users' needs and expectations is testified by the wealth of studies adopting a passenger's perspective when dealing with transit service quality issues (Eboli \& Mazzulla, 2007). The authorities are responsible for transport policy and law providers for operators accountable for implementing it. Greater Kuala Lumpur has been given priority in public transport infrastructure development in Malaysia. This study aims to investigate the effect of travel intention and the moderating effect of general service quality of public transport on travel behaviour among commuters in Kuala Lumpur.

\section{LITERATURE REVIEW}

Over the past decade, extensive studies on assessments of public transport services have been well documented in much global literature. Most of these studies were aimed at providing explanations towards travel passengers' motives for travelling via different modes of transportation (Tri et al. 2016), improving users' satisfaction and becoming more market-oriented (Tri et al. 2016, Ari et al., 2014; Ji \& Gao, 2010; Lai \& Chen, 2011). In this study, the researchers attempt to examine the role of attitude, social norms and personal norms predictors in affecting passengers' travel behaviour. On the other hand, service quality is proposed to have a moderating effect on the relationship between these direct predictors and travel behaviour. Drawing from the Theory of Planned Behaviour 
Rohana Ngah, Lennora Putit, Azmi Mat, Jamalunlaili Abdullah, Rohayu Ab Majid

Moderating Effect of Service Quality on Public Transport Travel Behaviour and Antecedents

literature, this study discusses the predictive components of passengers' intention to use public transportation for travel purposes, followed by a discussion on service quality and its moderating influence on such behaviour.

\section{TRAVEL BEHAVIOUR}

Travel behaviour is a decision-making process of commuters in choosing their preferences for transportation (Arroyo et al., 2020). In understanding the commuters' choice of transport, travel behaviour has been used widely in transportation studies. Also, personal characteristics, social interaction, environment, and habits have shown a positive effect on commuters (Liang et al. 2018).

\section{THEORY OF PLANNED BEHAVIOUR}

Theory of Planned Behaviour (TPB) (Ajzen, 1985; 1991) was developed following an extension of the socio-psychological Theory of Reasoned Action or TRA (Ajzen and Fishbein, 1980; Fishbein and Ajzen, 1975) as a result of the original model's limitations in dealing with behaviours over which people have incomplete volitional control. According to TPB, both attitudes toward behaviour (Act) and subjective norms (SN) are immediate determinants of intention to perform the behaviour. The TPB further proposes that the intention to perform a behaviour is the direct cause of such behaviour. It represents motivational components, that is, the extent to which a person will exercise conscious effort in carrying out any intended behavioural actions.

In capturing non-volitional aspects of behaviour, the Theory of Planned Behaviour incorporates an additional variable that is not typically associated with traditional attitude-behavioural model (e.g., Fisbein \& Ajzen, 1975). Specifically, it proposes that perceived behavioural control (PBC), in conjunction with attitude and subjective norms, is a direct predictor of behavioural intention. The TPB offers an excellent framework to explain mobility behaviour, to which it contains the central predictors to explain mobility behaviour. Also, the TPB is open to the inclusion of additional predictors to increase its predictive power (Madha et al. 2014) such as travel behavioural intention, attitude, social norm, and personal norm, and these are often examined (Martin et al., 2017; Ribeiro et al. 2017).

Attitude is a reflection of one's evaluation of performing any intended action (Ajzen, 2005). Attitude is the likelihood that a person will react with a particular response to a particular situation (Kim \& Kwon, 2018). Shen et al. (2019) state that attitude, an essential concept rooted in social psychology, refers to an inclination to the social environment (Shen et al. 2019). Attitudes are a positive predictor of intentions to use public transportation (Şimşekoğlu et al. 2015). 
Social and personal norms have been used widely in explaining intentions to choose eco-friendly travel options (Doran and Larsen, 2016. Under TPB, subjective norms (social norms) and personal norms significantly predicted the travel intention (Ajzen and Fishbein 2005).

\section{BEHAVIOURAL INTENTION}

Ajzen $(1985,1991)$ noted that behavioural intention is the cognitive representation of a person's readiness to perform a given behaviour, which is considered an immediate antecedent of actual behaviour. In the current context, the intention is broadly described as the passengers' propensity to adopt public transport travel behaviour within a progressive developing nation. It focuses on a one-dimensional behavioural intention: the tendency to use public transportation for travel purposes in terms of work or leisure. Travel intention has been widely discussed in recent literature. Travel intention describes how an individual is willing to adopt a behaviour (Rizky, 2017). Lai \& Chen (2011) found that passengers' intentions to use public transport are partly determined by factors such as attitude social influences and service expectations. Other studies such as Aqaq \& El Masry (2016), Zailani et al. (2016) and Simsekoglu et al. (2015) have also researched on the predictive nature of TPB and found significant effects of the psychological factors affecting travel intention.

\section{MODERATING EFFECT OF SERVICE QUALITY}

The French Association of Normalization defines service quality as a set of quality criteria and appropriate measures taken by public transport service providers (French Association of Normalization [FAN], 2002). The service quality of public transport relates to two levels of actors; the first level is authorities. The second level is service users that are the final customers (National Federation of Transport User Associations [NFTUA], 2013). As proposed by Gronroos (1984), the concept of service quality consists of two dimensions. Firstly, is technical quality, which reflects the levels of quality of delivery. Examples are the quality and effectiveness of transportation services for public transport. Secondly, a functional quality refers to how service is delivered, particularly the care and manners of the delivery personnel. In an attempt to achieve a high level of customer satisfaction, most researchers suggest that the service provider should deliver a high level of service quality as service quality is generally considered as an antecedent of customer satisfaction (Ona, Eboli \& Forciniti, 2016; Elliot, Li \& Choi, 2013). At the same time, service quality is also pertinent in ensuring that intention for a useful model of public transportation can be utilized by passengers effectively. In this study, perceived service quality is the evaluation of relational service (or customer services) and enabling service features (such as reliability, accessibility, fares, communication, comfort, safety, 
Rohana Ngah, Lennora Putit, Azmi Mat, Jamalunlaili Abdullah, Rohayu Ab Majid

Moderating Effect of Service Quality on Public Transport Travel Behaviour and Antecedents

and trip experience). Although service quality may have a significant impact on the propensity to use public transportation, it can be moderated by the fact that the passengers may not use it if the service provided is not found to be of their perceived expectations. Following the above, two main hypotheses are being developed and tested in this study. There are as follows:

H1: Travel Intention has a significant positive relationship to Travel Behaviour H2: Service Quality significantly moderates the relationship between Travel Intention and Travel Behaviour

\section{RESEARCH METHOD}

Data collection was carried out through a face-to-face questionnaire survey at ten stations of Light-Rail Transport (LRT) in Kuala Lumpur. A total of 938 respondents have participated; however, only 904 responses were usable. The instruments of measurements were adapted from previous authors and studies (Javid et al. 2013; Lai and Chen, 2011). Table 1 shows a sample of items of instrument measurements. Partial least-square structural equation modelling (PLS-SEM) using the Smart PLS 3.0 software (Hair, Ringle \& Sarstedt, 2017) was used to validate the measures developed and test the hypotheses. The analysis of the data is reported in two stages: measurement and structural model. The measurement model is to examine the relationship between latent variables using convergent validity and discriminant analysis. The structural model tests the inner model and the predictive relevance of the model and tests the hypotheses (Hair et al. 2017).

\section{THE RESULTS AND FINDINGS}

Females represented $53.6 \%$ of respondents. The majority are between $20-29$ years old $(61.7 \%)$, followed by below 20 years of age, $19 \%$. Most of the respondents are single $(78.2 \%$ ), and only $19.4 \%$ are married. More than $50 \%$ of respondents possess a degree in terms of education level. The majority of respondents earn less than RM2999 a month (43.8\%), and 54.4\% spend less than RM200 a month for transportation costs. Tables 2 shown demographic profiling. In presenting the multivariate analysis results using PLS, two stages of analysis, measurement, and structural models were carried out:

\section{Measurement Model}

The measurement model or outer model presents the outer model results to examine the loadings, reliability, and validity of the measures used to represent each construct (Chin, 2010) and the approach of PLS threshold values as suggested by Hair, Ringle, and Sarstedt (2011). The outer loadings of each variable showed good loadings. Two items were deleted due to low loading (less 
than 0.7); TA3 and PN2). As suggested by Hair et al. (2017), the factor loadings, composite reliability, and average variance extracted were used to assess convergence validity. The composite reliability values, as in Table 3 , which depict the degree to which the construct indicators indicate the latent, exceeded the recommended value of 0.7 (Hair et al., 2010). The average variance extracted, which reflects the overall amount of variance in the indicators accounted for by the latent construct, exceeded the recommended value of 0.5 (Hair et al., 2011). Therefore, the measures of all the variables/constructs have proper levels of convergent validity. The heterotrait-monotrait ratio of correlations (HTMT) was used as it is proven to be robust in testing discriminant analysis (Henseler et al. (2015). Table 3 showed that all variables value is below 0.9; therefore, discriminant validity is established.

Table 1: Sample of Item of instrument measurement

\begin{tabular}{|c|c|}
\hline Attitude & $\begin{array}{l}\text { I like traveling by public transport } \\
\text { Using public transport is convenient } \\
\text { Using public transport is time-efficient }\end{array}$ \\
\hline $\begin{array}{l}\text { Social } \\
\text { Norm }\end{array}$ & $\begin{array}{l}\text { People who are important to me always encourage me to use public } \\
\text { transport because it is safer/easier } \\
\text { People who are important to me always encourage me to use public } \\
\text { transport because it is cheaper } \\
\text { People who are important to me always use public transport for their } \\
\text { daily commuting trips }\end{array}$ \\
\hline $\begin{array}{l}\text { Personal } \\
\text { Norm }\end{array}$ & $\begin{array}{l}\text { Because of my values/principles, I feel an obligation to use public } \\
\text { transportation for everyday trips } \\
\text { I feel a responsibility to use public transport for every trip } \\
\text { I feel morally responsible for contributing to the betterment of the } \\
\text { urban environment and society }\end{array}$ \\
\hline $\begin{array}{l}\text { General } \\
\text { Service } \\
\text { Quality }\end{array}$ & $\begin{array}{l}\text { The public transport services provide good network coverageThe } \\
\text { public transport services have operating hours convenient to all its } \\
\text { customers } \\
\text { The public transport services' staff attend to complaints efficiently } \\
\text { The public transport services provide easy ticket purchasing system } \\
\text { The public transport services offer updates and the latest public } \\
\text { transport information } \\
\text { Physical facilities at the public transport services are visually appealin } \\
\text { g and clean }\end{array}$ \\
\hline
\end{tabular}


Rohana Ngah, Lennora Putit, Azmi Mat, Jamalunlaili Abdullah, Rohayu Ab Majid

Moderating Effect of Service Quality on Public Transport Travel Behaviour and Antecedents

\begin{tabular}{|l|l|}
\hline & $\begin{array}{l}\text { I like to travel by public transport because I can relax } \\
\text { Travel }\end{array}$ \\
Behaviour & $\begin{array}{l}\text { I want to travel by public transport because I feel safer from accident } \\
\text { I likel by public transport because it is economical } \\
\text { I prefer to travel using public transport to avoid traffic congestion }\end{array}$ \\
\hline
\end{tabular}

Table 2: Demographic profiling

\begin{tabular}{|c|c|c|c|}
\hline $\begin{array}{l}\text { PROFILE } \\
\mathrm{N}=904\end{array}$ & & FREQ & $\%$ \\
\hline \multirow{2}{*}{ Gender } & Female & 484 & 53.6 \\
\hline & Male & 420 & 46.4 \\
\hline \multirow{6}{*}{ Age } & $<20$ & 172 & 19.0 \\
\hline & $20-29$ & 558 & 61.7 \\
\hline & $30-39$ & 109 & 12.1 \\
\hline & $40-49$ & 37 & 4.1 \\
\hline & $50-59$ & 21 & 2.3 \\
\hline & $>60$ & 7 & .8 \\
\hline \multirow{3}{*}{ Marital Status } & Single & 707 & 78.2 \\
\hline & Married & 175 & 19.4 \\
\hline & Others & 22 & 2.4 \\
\hline \multirow{5}{*}{ Education } & SPM/STPM & 154 & 17.0 \\
\hline & Certificate/Diploma & 217 & 24.0 \\
\hline & Degree & 455 & 50.3 \\
\hline & Post-Grad & 38 & 4.2 \\
\hline & Others & 40 & 4.4 \\
\hline \multirow{7}{*}{$\begin{array}{l}\text { Employment } \\
\text { status }\end{array}$} & Not Working & 34 & 3.8 \\
\hline & Student & 519 & 57.4 \\
\hline & Executive & 120 & 13.3 \\
\hline & Manager & 55 & 6.1 \\
\hline & Self-Employed & 53 & 5.9 \\
\hline & $\begin{array}{l}\text { Technical/labour } \\
\text { Intensive }\end{array}$ & 29 & 3.2 \\
\hline & Others & 94 & 10.4 \\
\hline \multirow{5}{*}{ Income } & Under RM2,999 & 273 & 43.8 \\
\hline & RM3,000-RM4,999 & 149 & 23.9 \\
\hline & RM5,000-RM9,999 & 128 & 20.5 \\
\hline & $\begin{array}{l}\text { RM10,000- } \\
\text { RM14,999 }\end{array}$ & 51 & 8.2 \\
\hline & Over RM15,000 & 22 & 3.5 \\
\hline \multirow{3}{*}{$\begin{array}{l}\text { Household } \\
\text { Vehicle }\end{array}$} & Motorcycle & 36 & 39 \\
\hline & Bicycle & 150 & 16.6 \\
\hline & Cars & 686 & 75.9 \\
\hline
\end{tabular}


PLANNING MALAYSIA

Journal of the Malaysia Institute of Planners (2020)

Table 3: Reliability and Discriminant Analysis

\begin{tabular}{lcccccc} 
& CR & AVE & $\mathbf{1}$ & $\mathbf{2}$ & $\mathbf{3}$ & $\mathbf{4}$ \\
\hline Attitude & 0.864 & 0.760 & & & & \\
General Service Quality & 0.958 & 0.657 & 0.751 & & & \\
Personal Norms & 0.879 & 0.645 & 0.966 & 0.704 & & \\
Social Norms & 0.901 & 0.694 & 0.808 & 0.495 & 0.748 & \\
Travel Behaviour & 0.877 & 0.705 & 0.795 & 0.660 & 0.786 & 0.609 \\
\hline
\end{tabular}

\section{Structural Model}

The structural model or inner model examines the hypothesized relationships among the constructs in the research model (Hair et al. 2017). A total of $47.7 \%$ of the variance $\left(\mathrm{R}^{2}\right)$ in travel behaviour showed a reliable predictive explanatory power of variance explained by antecedents of travel intention and general service quality of public transport, as shown in Figure 1. The general service quality significantly moderates the relationship between travel intention and travel behaviour, even though in a reverse direction. Travel intention has a significant effect on travel behaviour $(\boldsymbol{\beta}=0.460$ with a t-value of 12.491); therefore, $\mathrm{H} 1$ is supported. General Service quality has a significant impact on travel behaviour with path ( $\boldsymbol{\beta})$ coefficient of 0.263 and t-value of 7.611. The general service quality is significantly moderate the relationship between travel intention and travel behaviour, even though in a reverse direction $(\beta--0.043$, $\mathrm{t}=3.115$ ). Table 4 and Table 5 present the findings of the total effect and hypotheses of the study.

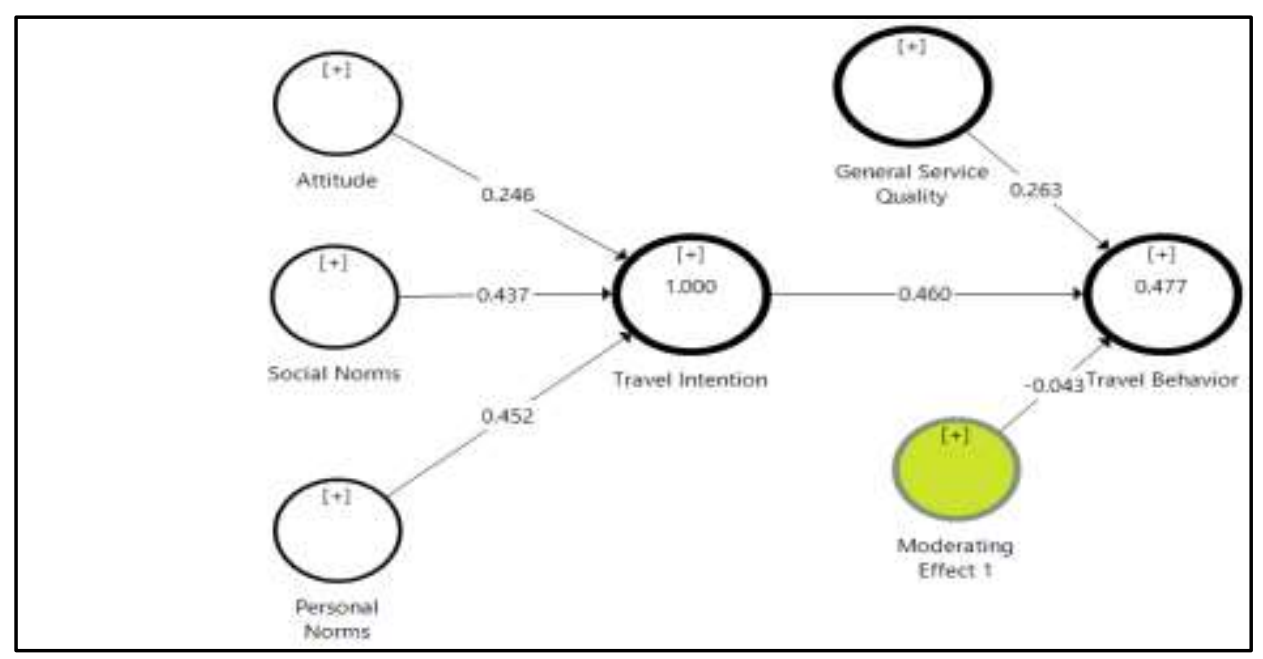

Figure 1: The Structural Model 
Rohana Ngah, Lennora Putit, Azmi Mat, Jamalunlaili Abdullah, Rohayu Ab Majid

Moderating Effect of Service Quality on Public Transport Travel Behaviour and Antecedents

Table 4: Total Effect

\begin{tabular}{lrrrc} 
& $\boldsymbol{\beta}$ & SD & T-value & P \\
\hline $\begin{array}{l}\text { General Service Quality -> Travel } \\
\text { Behaviour }\end{array}$ & 0.263 & 0.035 & 7.611 & 0.000 \\
Moderating Effect 1 -> Travel & & & & \\
Behaviour & -0.043 & 0.014 & 3.115 & 0.002 \\
Travel Intention -> Travel Behaviour & 0.460 & 0.037 & 12.491 & 0.000 \\
\hline
\end{tabular}

Table 5: Hypotheses Findings

\begin{tabular}{lllll} 
& $\boldsymbol{\beta}$ & T-value & $\mathbf{P}$ & Remarks \\
\hline $\begin{array}{l}\text { H1: Travel Intention has a significant } \\
\text { positive relationship to Travel Behaviour }\end{array}$ & 0.460 & 12.491 & 0.000 & Supported \\
$\begin{array}{l}\text { H2: Service Quality significantly } \\
\text { moderates the relationship between }\end{array}$ & -0.043 & 3.115 & 0.002 & Supported \\
Travel Intention and Travel Behaviour & & & & \\
\hline
\end{tabular}

\section{DISCUSSION AND CONCLUSION}

This paper aims to investigate the effect of travel intention and general service quality on travel behaviour of public transport in Kuala Lumpur. Travel intention comprises attitude, subjective norms, and personal norms, which showed a significant positive relationship to travel behaviour as supported by previous studies (Maduwanthi et al. 2015; Ng and Acker, 2018; Irtemih et al. 2018). This study showed that most public transport users were women, which is in line with a previous study by Kuhnimhof et al. (2006) that women use more PT for many reasons. It is also important to note that most of the respondents were young adults who earned less than RM3000 a month; thus, public transportation would be a transportation solution. The result is similar to previous studies that public transport decreases as age and income increase (Chowdhury and Ceder, 2016).

Therefore, this study adds another contribution to the body of knowledge. This study also examined the moderating effect of general service quality of transportation services ranging from staff to infrastructure. It showed a weak strength in the relationship between travel intention and behaviour. There is a possibility that commuters did not relate their intention to use public transport with the existing services given by the service provider. The reverse direction of the moderating effect of general service quality indicates that the more commuters intend to use, the less general service quality influences their travel behaviour. Caruanna et al. (1997) emphasized that service quality's reverse effect does not mean that service quality is not essential, but perhaps other things are more relevant to commuters. Travel behaviour does not depend on general service quality alone. The result is also similar to the study done by Minhans et al. (2015) that highlighted commuters' frustration relating to service quality of public transport. It is important to note that in this study, only general service quality is utilized. However, this study provides an excellent lead to pursue the 
improvement and visibility of excellent service quality. This study is not without limitations. Firstly, the data was collected at stations; the commuters' willingness to participate is very challenging. Secondly, due to time constraint, some of the demographic section was not completed. Future research should explore the tangible and intangible elements of service quality to encourage higher public transport ridership.

\section{ACKNOWLEDGEMENTS}

The authors would like to thank Universiti Teknologi MARA (UiTM) for the support and funding of the study through the internal grant (600-IRMI/MYRA 5/3/MITRA (002/2017)-2. The authors would also like to thank all the departments, organizations, and individuals who had contributed to this study.

\section{REFERENCES}

Agensi Pengangkutan Awam Darat (2017), Government's initiative on public transport results in increased ridership. https://www.apad.gov.my/en/media-centre/mediareleases/2017/governments-initiative-public-transport-results-increased-ridership

Agag, G., \& El-Masry, A.A. (2016). Understanding consumer intention to participate in online travel community and effects on consumer intention to purchase travel online and WOM: An integration. Computers in human behaviour.60, 97-111

Ajzen, I. (1985). From Intentions to Actions: A Theory of Planned Behavior. In J. K. Beckman (Ed.), Action control: From cognition to behavior. Englewood Cliffs, New Jersey: Prentice Hall.

Ajzen, I. (1991). The Theory of Planned Behavior . Organizational Behavior and Human Decision Process, 50, 179-211.

Ajzen, I., Fishbein, M. (1980). Understanding Attitudes and Predicting Social Behavior. Englewood Cliffs, NJ: Prentice Hall.

Ari K.M. Tarigan,Yusak O. Susilo \&Tri B. Joewono (2014). Segmentation of paratransit users based on service quality and travel behaviour in Bandung, Indonesian Transportation Planning and Technology.

Arroyo, R., Ruiz, T., Mars, L. Rasouli, S. \& Timmermans, H. (2020). Influence of values, attitudes towards transport modes and companions on travel behavior, Transportation Research Part F 71, 8-22

Caruana, A., Money,A.H. \& Berthon, P.R. (2000). Service quality and satisfaction- the moderating role of value, European Journal of Marketing, 34 (11/12), 1338-1352.

Choi,C.C. \& Loh,N. (2013). Transport Policies and Patterns: A comparison of five Asian Cities. Journeys. 69-78.

Cronin, B. \& Hult (2000). Assessing the effects of quality, value, and customer satisfaction on consumer behavioral intentions in service environments. Journal of Retailing, 76(2), 193-218. doi: 10.1016/S0022-4359(00)00028-2

De Oña, J., de Oña.R., Eboli, L. \& Forciniti,C. (2016). Transit passengers' behavioural intentions: the influence of service quality and customer satisfaction. A: Transport Science, 12( 5)

Doran, R., \& Larsen, S. (2016). The relative importance of social and personal norms in 
Rohana Ngah, Lennora Putit, Azmi Mat, Jamalunlaili Abdullah, Rohayu Ab Majid

Moderating Effect of Service Quality on Public Transport Travel Behaviour and Antecedents

explaining intentions to choose eco-friendly travel options. International Journal of Tourism Research, 18(2), 159-166. https://doi.org/10.1002/jtr.2042

Eboli, L. \& Mazzulla, G. (2007). Service Quality Attributes Affecting Customer Satisfaction for Bus Transit. Journal of Public Transportation. 10(10) .5038/23750901.10.3.2.

Elliot,S., Li,G. \& Choi,C. (2013) Understanding service quality in a virtual travel community environment. Journal of Business Research, 66( 8), 1153-1160

Eugene W. Anderson, Claes Fornell and Donald R. Lehmann (1994). Customer Satisfaction, Market Share, and Profitability: Findings from Sweden. Journal of Marketing.58( 3), 53-66

Fishbein, M., Ajzen, I. (1975). Belief, Attitude, Intention and Behavior. Reading, MA.

Forward, S. (2019). Views on Public Transport and How Personal Experiences Can Contribute to a More Positive Attitude and Behavioural Change, Social Science, 8, 47; doi:10.3390/socsci8020047

French Association of Normalization (FAN) (2002). Transportation, logistics and services . NF EN 13816, X50-805, 36.

French Association of Normalization (FAN) (2012). Certification reference system. NF 281, 70.

Groonroos. C (1984) Service Quality and its Implication on Marketing. European Journal of Marketing. 18( 4)

Irtemih, H., Ismail, A. , Borhan, M.N., muhamad muhammad das, A. msori \& Alshetwi, A.B.Z. (2018). Case study of the behavioural intentions of public transportation passengers in Kuala Lumpur. Case Studies on Transport Policy. doi.0.1016/j.cstp.2018.05.007.

Javid, M.A., Okamura, T. Nakamura, F., Tanaka, S., Wang, R. (2013). Factors Influencing the Acceptability of Travel Demand Management (TDM) Measures in Lahore: Application of Behavioral Theories. Proceedings of the Eastern Asia Society for Transportation Studies, 9, 2013

Ji, J. \& Gao, X. (2010). Analysis of People's Satisfaction with Public Transportation in Beijing. Habitat International. 34(4): 464-470. doi:10.1016/j.habitatint.2009.12.003.

Hair, J. F., Hollingsworth, C. L., Randolph, A. B., \& Chong, A. Y. L. (2017a). An updated and expanded assessment of PLS-SEM in information systems research. Industrial Management \& Data Systems, 117(3), 442-458

Hair, J. F., Ringle, C. M., \& Sarstedt, M. (2011). PLS-SEM: Indeed a silver bullet. Journal of Marketing Theory and Practice, 19(2), 139-151

Lai,W.T. \& Chen, C.F. (2011) Behavioral intentions of public transit passengers--The roles of service quality, perceived value, satisfaction and involvement. Transport. Policy 18(2), 318-325.

Land Transport Authority (2018). Retrieved at https://www.lta.gov.sg/content/ltagov/en/who_we_are/statistics_and_publication s/statistics.html

Liang, Q., Weng. J., Zhou,W., Santamaria,SB., Ma,J \& Rong, J. (2020). Individual Travel Behavior Modeling of Public Transport Passenger Based on Graph Construction, Journal of Advanced Transportation, https://doi.org/10.1155/2018/3859830

Kim, SB \& Kwon, KJ. (2018). Examining the Relationships of Image and Attitude on 
Visit Intention to Korea among Tanzanian College Students: The Moderating Effect of Familiarity, Sustainability, 10, 360; doi:10.3390/su10020360

Madha,A., Salman, A.D. , Hussain, A.D., Borhan, N. \&, Rahmat, R.A.o.K. (2014) Analysis Of Travel Behaviour In Petaling Jaya, Malaysia: An Application Of The Theory Of Planned Behaviour. Archives of Transport. 8(2). doi: $10.5604 / 08669546.1218791$

Maduwanthi, M. , Ashu, M., Rajapakse, R.P.C. J., Dharmawansa, A. \& Shusaku, N. (2015). Factors Influencing to Travel Behavior on Transport Mode Choice. International Journal of Affective Engineering. 10.5057/ijae.IJAE-D-15-00044.

Mat, A., Saiful Bahry, N., Kori, N.L., Abdul Munir, Z., and Mohd Daus, N. (2019). The Influence of Service Quality And Passenger Satisfaction Towards Electric Train Services (ETS): A PLS-SEM Approach. Foundations of Management. 11, 57-64.

Minhans, A., Shahid,S. \& Hassan, S.A. (2015). Assessment of Bus Service-Quality using Passengers' Perceptions, Jurnal Teknologi, 73 (4), 61-67

National Federation of Transport User Associations (NFTUA) (2013). Travelers' expectations regarding quality of service: analysis of NFTUS. Directorate General for Infrastructure, Transport and the Sea, 118.

Polat , C. (2012). The Demand Determinants for Urban Public Transport Services: A Review of the Literature. Journal of Applied Sciences, 12, 1211-1231.

Shen K, Geng C and Su X (2019) Antecedents of Residents' Pro-tourism Behavioral Intention: Place Image, Place Attachment, and Attitude. Frontier in Psychology. 10:2349. doi: 10.3389/fpsyg.2019.02349

Şimşekoğlu,O., Nordfjærn, T. \& Rundmo, T. (2015). The role of attitudes, transport priorities, and car use habit for travel mode use and intentions to use public transportation in an urban Norwegian public. Transport Policy, 42, 113-120

Tai, T., Ngah, R., Shah, M.Z., Mohammed, Y. \& Ali, Al. (2016). Modelling Travel Demand Management Measurements towards Travel Behaviour with PsychoSocial, Trip Chain Attributes and Quality of Life: A Conceptual Paper. Journal of Traffic and Logistics Engineering. 4, 141-147. 10.18178/jtle.4.2.141-146.

Tri B. Joewono, Ari K.M. Tarigan, Yusak O. Susilo. (2016) Road-based public transportation in urban areas of Indonesia: What policies do users expect to improve the service quality? Transport Policy, 49, 114-124.

Wei-Shiuen Ng and Ashley Acker (2018). Understanding Urban Travel Behaviour by Gender for Efficient and Equitable Transport Policies, International Transport Forum, Paris, France. https://www.itf-oecd.org/sites/default/files/docs/urbantravel-behaviour-gender.pdf

Zailani, S., Iranmanesh, M., , Masron, T.A. \& Chan, T.H. (2016). Is the intention to use public transport for different travel purposes determined by different factors? Transportation Research Part D: Transport and Environment, 49, 18-24.

Zhang, K., \& Batterman, S. (2013). Air pollution and health risks due to vehicle traffic. The Science of the total environment, 450-451, 307-316. https://doi.org/10.1016/j.scitotenv.2013.01.074 